\title{
Effect of Brand Identity and Brand Image On Customer Loyalty Case Study In Daihatsu Car Consumer
}

\author{
Catur Rachmad Susetyo ${ }^{\mathrm{a}^{*}}$, Sengguruh Nilowardono ${ }^{\mathrm{b}}$, Ani Wulandari ${ }^{\mathrm{c}}$ \\ ${ }^{a}$ Faculty of Economics anda Business, Narotama University Management Study Program, catur.rachmad7@gmail.com \\ ${ }^{b}$ Faculty of Economics anda Business, Narotama University Surabaya, Jawa Timur, sengguruh@narotama.ac.id \\ ${ }^{c}$ Faculty of Economics anda Business, Narotama University Surabaya, Jawa Timur, ani.wulandari@narotama.ac.id
}

\begin{abstract}
Daihatsu Motor Co., Ltd. is the oldest Japanese car company known for its small car products or more agreed. The number of Daihatsu car consumers is quite a lot, in making purchases. This study aims to analyze the effect of brand identity and brand image on customer loyalty. This type of research uses a quantitative approach. Data collection uses interviews, observation, and questionnaire distribution. Using the nonprobability method with a purposive sampling approach. The population of this research is Daihatsu car consumers with a sample of 60 respondents. The analytical method used is SPSS v.20. Based on the results of this study concluded that brand identity and brand image have a significant effect on customer loyalty.
\end{abstract}

Keywords: Brand Identity, Brand Image, Customer Loyalty

\section{Introduction}

Customers' needs for transportation are increasing. This triggers every car company to create a great brand identity to gain brand trust from customers. Brand identity is what is meant by a brand and how it is felt in the world. Those are the words, thoughts, and images that come to mind when consumers engage with a brand and how it can make consumers feel it. But consumer behavior that is expected to continue to exist for companies is loyalty. Loyalty means that customers continue to make regular purchases.

According to Kotler (2008), customer loyalty, is a commitment held in depth to buy or support a product or service that is preferred in the future despite the influence of the situation and marketing efforts that cause customers to switch. Customer loyalty is a key to success for a company, customer loyalty is not only for a short period of time but a long period of time in a competition and can be an advantage in a competition. Loyal customers will not move and are easily influenced by the company or other products. Customer loyalty is an important key to maintaining the company's position in the market and creating efficiency and effectiveness of the company because if the company does not build customer loyalty then the company may have to spend more money and more energy to find new customers.

Customer loyalty in general can be interpreted as a person's loyalty to a product, both certain goods and services. Brand image is what consumers think and feel when hearing or seeing a brand name.

A positive consumer image of a brand makes it possible for consumers to make purchases. A better brand is also the basis for building a positive company image. Brand perception from customers influences brand trust income which is very related to customer loyalty.

This study aims to show that brand identity influences customer loyalty, brand image influences the trust of Daihatsu car customers in urban areas. Also brand image and brand identity affect Daihatsu's customer loyalty.

\footnotetext{
* Corresponding author.

E-mail address: catur.rachmad7@gmail.com (Catur Rachmad Susetyo)
} 
According to Tjiptono (2000) brand image, namely customer commitment to a brand, store or supplier based on the very positive nature of long-term purchases. Brand identity is a behavioral impulse to make repeated purchases and to build consumer loyalty to a product or service produced by the business entity which takes a long time through a process of buying that occurs repeatedly.

\section{Literature review}

\subsection{Brand Identity}

According to Kotler and Keller (2012: 258) that is a name, term, sign, symbol, design, combination of these, intended to identify goods or services from a seller or group of sellers to differentiate goods or services from competitors. Brand identity can be in the form of signs or symbols that can provide the identity of certain goods or services which can be in the form of words, pictures or can combine both (Alma; 2012: 147). By giving a brand, it will be easier for consumers to distinguish products or services produced by a company. Brand identity plays an important role in the sale of a product because if a brand that is positioned in the market has a good image, then it will be one of the drivers to grow consumer purchase intention.

\subsection{Brand Image}

Brand image is a series of associations that exist in the minds of consumers towards a brand, usually organized into a meaning (Aaker 1994). Brand image is also said to be a vision and trust that is hidden in the minds of consumers as a reflection of the association that is stuck in consumers' memories (Kotler 2008). Brand image can be measured in three categories:

1) Benefits of a brand association (favorability of brand association)

A brand creates a positive attitude if the attributes and benefits of the brand can satisfy the needs and desires of consumers.

2) Strength of brand association (strength of brand association)

Associations are formed from information that enters consumers' memories and how that information survives as part of a brand image

3) The uniqueness of brand association

Unique and attractive brands can create strong associations in the customer's mind.

\subsection{Customer loyalty}

According to Griffin (2003) a customer is someone who becomes accustomed to buying a product and service. Habits are formed through frequent purchases and interactions over a certain period of time.

Customer loyalty is often associated with repurchase behavior. According to Griffin (2003), the concept of customer loyalty is more associated with behavior than behavior. If a person is a loyal customer, he will show buying behavior that is defined as nonrandom purchases that are disclosed from time to time by several decision-making units. A loyal customer has specific prejudices about what to buy and from whom. In addition, loyalty shows the condition of a certain period of time and requires that the purchase occurs not less than twice.

\section{Methods}

\subsection{Hypothesis}

Based on the formulation of the problem and description of the literature review the authors propose the following research hypotheses: 
H1: There is a partial effect of the components consisting of Brand Identity and Brand Image variables on Customer Loyalty using Daihatsu cars

H2: There is a simultaneous effect of components consisting of Brand Identity and Brand Image variables on Customer Loyalty using Daihatsu cars

H3: Brand Identity, Citra Meerek has a significant effect on customer loyalty in using Daihatsu cars

\subsection{Types of research}

This study uses a questionnaire or (questionnaire). In collecting data the data source used is primary data. The data was obtained from the distribution of 60 consumer Daihatsu car questionnaires.

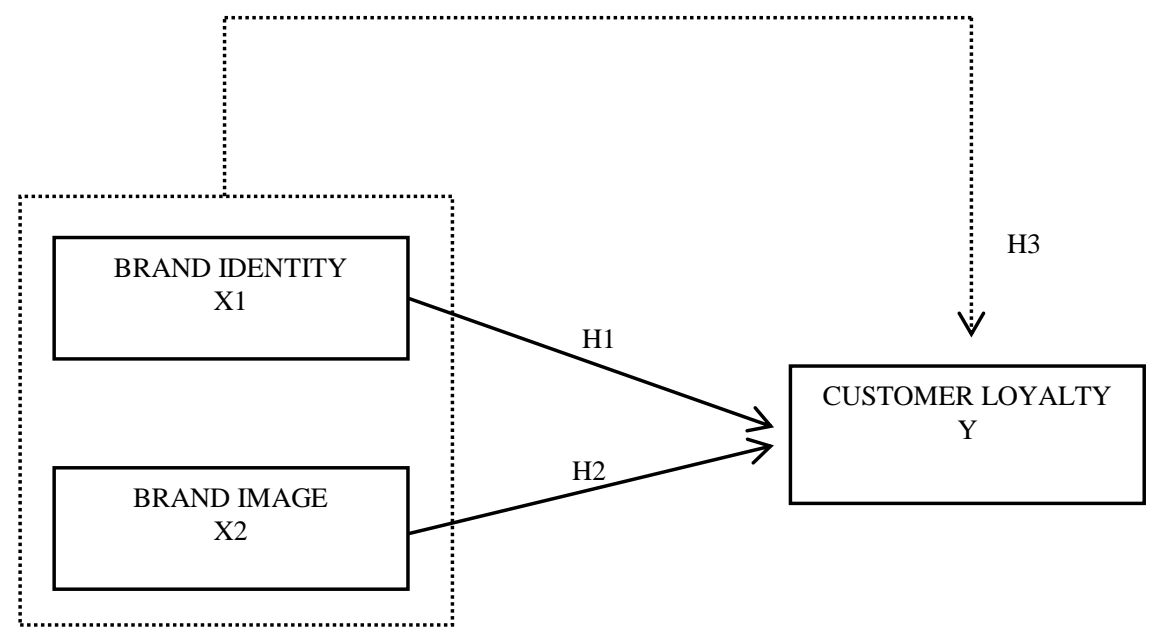

Figure 1 Thinking Framework

\subsection{Population}

The population in this study are 60 Daihatsu car consumers.

\subsection{Types, Sources and Techniques of Data Collection}

The type of data used in this study uses primary data. Primary data is a source of research data obtained directly from the original source not through intermediary media.

\subsection{Multiple Linear Regression Analysis}

The analysis technique used in this study is multiple linear regression. In order to know the effect of the independent variable $(\mathrm{X})$ on the dependent variable $(\mathrm{Y})$ the linear regression equation is used as follows:

with:

$$
Y=a+b_{1} X_{1}+b_{2} X_{2}+e
$$

$$
\begin{array}{ll}
Y & =\text { employee performance } \\
b_{1}, b_{2} & =\text { variable coefficients } \\
X_{1} & =\text { brand identity } \\
X_{2} & =\text { brand image } \\
e & =\text { error (error term) }
\end{array}
$$




\section{Results and discussion}

\subsection{Validity test}

Table 1 Result of Validity Test

\begin{tabular}{|c|c|c|c|c|}
\hline Variable & Indicator & $\begin{array}{l}\text { Corrected Item- } \\
\text { Total Correlation }\end{array}$ & R-Table & Result \\
\hline \multirow{5}{*}{ Brand Identity $\left(\mathrm{X}_{1}\right)$} & $\mathrm{X} 1.1$ & 0,847 & 0,214 & Valid \\
\hline & $\mathrm{X} 1.2$ & 0,879 & 0,214 & Valid \\
\hline & $\mathrm{X} 1.3$ & 0,729 & 0,214 & Valid \\
\hline & $\mathrm{X} 1.4$ & 0,814 & 0,214 & Valid \\
\hline & $\mathrm{X} 2.1$ & 0,736 & 0,214 & Valid \\
\hline \multirow{3}{*}{ Brand Image $\left(\mathrm{X}_{2}\right)$} & $\mathrm{X} 2.2$ & 0,686 & 0,214 & Valid \\
\hline & $\mathrm{X} 2.3$ & 0,811 & 0,214 & Valid \\
\hline & $\mathrm{X} 2.4$ & 0,862 & 0,214 & Valid \\
\hline \multirow{4}{*}{$\begin{array}{l}\text { Customer Loyalty } \\
\text { (Y) }\end{array}$} & $\mathrm{Y} 1$ & 0,787 & 0,214 & Valid \\
\hline & $\mathrm{Y} 2$ & 0,711 & 0,214 & Valid \\
\hline & Y3 & 0,757 & 0,214 & Valid \\
\hline & Y4 & 0,893 & 0,214 & Valid \\
\hline
\end{tabular}

Based on table 1can be seen the value of $r$ count is greater than $r$ table $(0.214)$ which means that each indicator variable is valid, so it can be concluded that this indicator can be used to measure the research variables.

\subsection{Reliability test}

Table 2 Result of Realibility Test

Reliability Statistics

\begin{tabular}{r|r}
\hline Cronbach's Alpha & \multicolumn{1}{|c}{ N of Items } \\
\hline 0,931 & 12 \\
\hline
\end{tabular}

From the reliability test table the research variables above show that all Cronbach alpha values of both dependent and independent variables are declared reliable or able to be accepted because they have values above 0.6, which means the questions from the research questionnaire are said to be reliable or reliable.

\subsection{Classical assumption}

\subsection{Normality test}

From the table 3 that the sig. value of each variable is 0.05 , therefore the variable is able to say normally distributed. 
Table 3 Result of Normality Test

One-Sample Kolmogorov-Smirnov Test

\begin{tabular}{|c|c|c|c|c|c|}
\hline & & Total X1 & Total X2 & & \\
\hline $\mathrm{N}$ & & 60 & 60 & & \\
\hline \multirow[t]{2}{*}{ Normal Parameters ${ }^{\mathrm{a}, \mathrm{b}}$} & Mean & 12.63 & 12.95 & & \\
\hline & Std. Deviation & & & 3.993 & 4.087 \\
\hline \multirow[t]{3}{*}{ Most Extreme Differences } & Absolute & .146 & .137 & & \\
\hline & Positive & & & .092 & .082 \\
\hline & Negative & & & -.137 & -.096 \\
\hline Kolmogorov-Smirnov Z & & 1.134 & 1.061 & & \\
\hline Asymp. Sig. (2-tailed) & & .152 & .210 & & \\
\hline
\end{tabular}

a. Test distribution is Normal.

b. Calculated from data.

\subsection{Multicollinearity Test}

Table 4 Result of Determination Coeficient

\begin{tabular}{|c|c|c|c|}
\hline \multicolumn{4}{|c|}{ Coefficients $^{\mathrm{a}}$} \\
\hline \multicolumn{2}{|c|}{ Model } & \multicolumn{2}{|c|}{ Collinearity Statistics } \\
\hline & & Tolerance & VIF \\
\hline \multirow[t]{3}{*}{1} & (Constant) & & \\
\hline & $\mathrm{X} 1$ & ,916 & 1,091 \\
\hline & $\mathrm{X} 2$ & ,916 & 1,091 \\
\hline
\end{tabular}

a. Dependent Variable: Total Y1

The table 4 shows that the VIF value for the independent variable is less than 10 . So that it can be said that there are no symptoms of multicollinearity approximately each of the independent variables.

\subsection{Heteroscedasticity test and glacial test}

In the figure 2, it is said heteroscedasticity if the image is scattered and does not overlap from the line of numbers 0 on $\mathrm{X}$ and $\mathrm{Y}$, so heteroscedasticity does not occur.

Based on table 5, in the glacier test above it is said that to strengthen the Heteroscedasticity test where the results of the variable work motivation $(\mathrm{X} 1)$, work competence $(\mathrm{X} 2)$, and employee performance $(\mathrm{Y})$ constant of the variable is more than 0.05 (significant). 


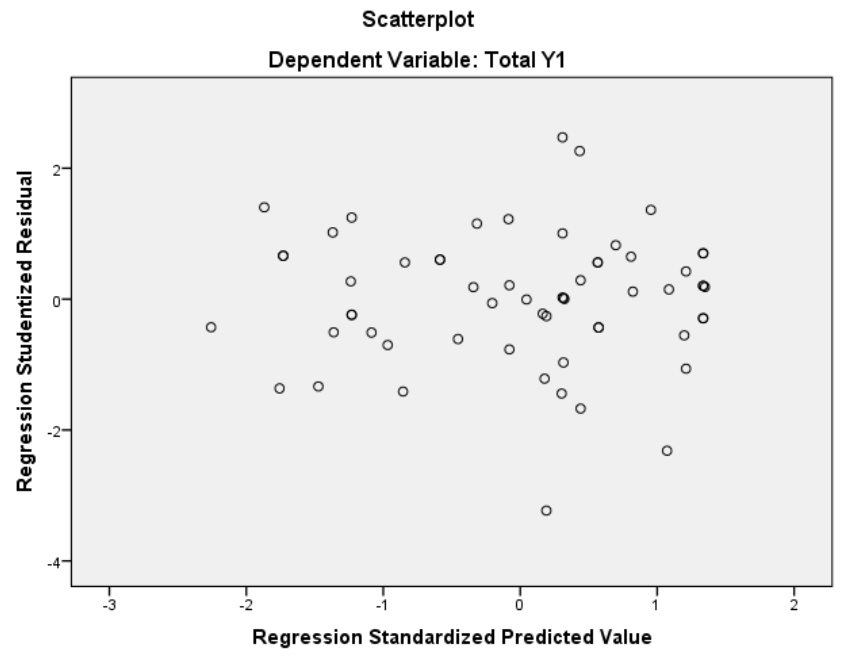

Figure 2 Scatterplot of Result of heteroskedastic

Table 5 Result of heteroskedastic

\begin{tabular}{|c|c|c|c|c|c|c|}
\hline \multicolumn{7}{|c|}{ Coefficients $^{\mathrm{a}}$} \\
\hline \multirow[t]{2}{*}{ Model } & & \multicolumn{2}{|c|}{ Unstandardized Coefficients } & $\begin{array}{l}\text { Standardized } \\
\text { Coefficients }\end{array}$ & \multirow[t]{2}{*}{$\mathrm{t}$} & \multirow[t]{2}{*}{ Sig. } \\
\hline & & B & Std. Error & Beta & & \\
\hline \multirow{3}{*}{1} & (Constant) & 1.198 & .925 & & 1.294 & 0.201 \\
\hline & Total X1 & .444 & .122 & .448 & 3.645 & 0.001 \\
\hline & Total X2 & 467 & .126 & 456 & 3.716 & $<0.001$ \\
\hline
\end{tabular}

a. Dependent Variable: Total Y1

\subsection{Simultaneous Hypothesis}

\subsection{T test}

Table 6 Result of T test

Coefficients $^{\mathrm{a}}$

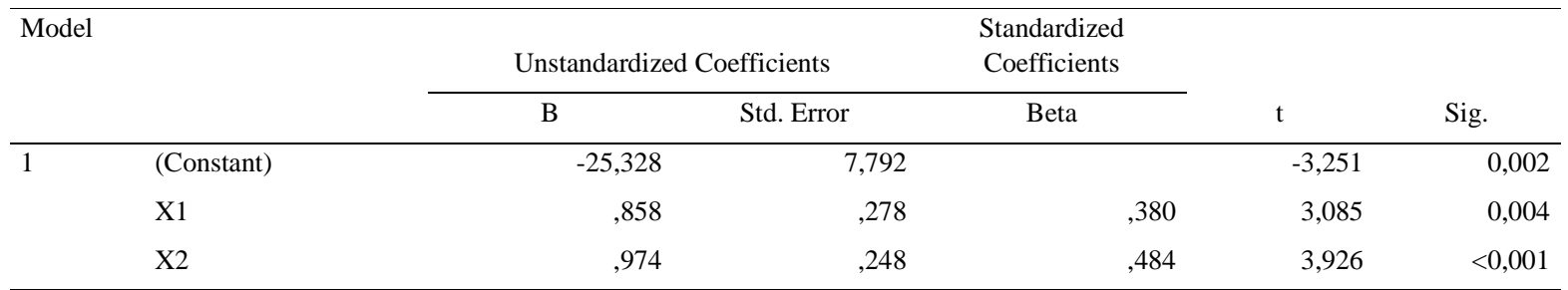

a. Dependent Variable: Y Kinerja karyawan

From the coefficients table 6 obtained partial hypothesis test results as follows:

1. the influence of work motivation variables (X1) on employee performance (Y) 
The results of the analysis obtained a significant value of 0.004 (less than 0.005 ) which means that the variable of work motivation (X1) has a significant effect on employee performance (Y).

2. the effect of work competency variables (X2) on employee performance (Y)

The results of the analysis of work competency variables are obtained with a significant value of 0,000 (less than $0.005)$ which means that the work competency variable $(\mathrm{X} 2)$ has a significant effect on employee performance $(\mathrm{Y})$.

4.7 F test

Table 7 Result of F test

\begin{tabular}{rlrrrrr}
\multicolumn{7}{c}{ ANOVA $^{\mathbf{a}}$} \\
Model & & Sum of Squares & Df & Mean Square & \multicolumn{1}{c}{ F } & \multicolumn{1}{c}{ Sig. } \\
\hline \multirow{2}{*}{1} & Regression & 742.877 & 2 & 371.439 & 87.209 & $<0.001^{\text {b }}$ \\
& Residual & 242.773 & 57 & 4.259 & & \\
& Total & 985.650 & 59 & & & \\
\hline
\end{tabular}

a. Dependent Variable: Total Y1

b. Predictors: (Constant), Total X2, Total X1

From the ANOVA table above, it can be said that the results of the simultaneous hypothesis test with the calculated $\mathrm{F}$ value is based on the table data above it is known that the value obtained is 87.209. Also obtained a significance value of $0,000<0.05$. Then $\mathrm{Ha}$ is accepted, meaning that the brand identity variable (X1) and brand image (X2) simultaneously have a significant effect on customer loyalty (Y) of the Daihatsu car.

\section{Conclusions and suggestions}

\subsection{Conclusion}

a. Brand Identity Variable (X1) does not have a significant effect partially on customer loyalty variables (Y). This is indicated by the significance value of greater than 0.05 which is equal to 0.469 . Based on these results it can be concluded that the Daihatsu brand identity does not have a significant effect on customer loyalty for Daihatsu cars.

b. Brand Image Variable (X2) has a partially significant effect on customer loyalty variables (Y). This is indicated by the significance value of less than 0.05 which is equal to 3.647. Based on these results it can be concluded that the Daihatsu brand image, especially in terms of creating new products, old product modifications, current levels and differences with other cars and improving the quality of the car has a significant influence on customer loyalty for Daihatsu cars.

c. The Brand Identity Variable (X1) and Brand Image (X2) have a significant simultaneous effect on the customer loyalty variable $(\mathrm{Y})$. This is indicated by the significance value of less than 0.05 which is equal to 0,000. Based on these results it can be concluded that brand identity and brand image together have a significant effect on customer loyalty for Daihatsu cars.

\subsection{Recommendations}

For companies, the increasingly intense competition between car manufacturers, the researchers recommend that Daihatsu pay attention to the following:

a. Continue to improve brand identity even though its influence is significant, brand identity still has a role in the basis of consumer decision making. 
b. Daihatsu must also continue to improve its ability to innovate. In this research the brand image must be continuously improved so that it can affect customer loyalty very well. This can be done by modifying the old car, fixing some components so that they have a higher sale value. That way consumers will be more interested in digging up information and growing customer loyalty in Daihatsu cars.

\section{References}

Andreani, F., Taniaji, TL, \& Made Puspitasari, RN (2012) . The Impact of Brand Image Towards Loyalty with Satisfaction as A Mediator in McDonald's. Journal of Management and Entrepreneurship, 14 (1). https://doi.org/10.9744/jmk.14.1.64-71

Ardiani, E., \& Murwatiningsih. (2017). Building Consumer Loyalty Through Brand Image, Service Quality and Consumer Satisfaction. Management Analysis Journal, 6 (3), 274-284.

In, F., Tarnovskaya, V., Chao, H., \& Panpan, Q. (2009). The Relationship between Brand Identity and Customer Loyalty A case of Sony Ericsson. 113. Retrieved from http://citeseerx.ist.psu.edu/viewdoc/download;jsessionid=ADC0EC372328414B003DE10A129DCDF8?doi= 10.1.1.455.2001\&rep=rep1\&type $=$ pdf

George, S. (2015). Brand Identity and Loyalty Customers: Evidence from the Nigeria Telecommunication Industry. 3 (6), 1-8.

Ghozali, I. (2005). Multivariate Analysis Application with SPSS program. Semarang: Diponegoro University Publisher Agency.

Hengestu, N., \& Iskandar, D. A. (2017). Effect of Brand Image and Price on Customer Loyalty in Bottled Drinking Water. Journal of Management and Business Research (JRMB) UNIAT Faculty of Economics, 2 (3), 363372. https://doi.org/10.36226/jrmb.v2i3.70

Lindeberg, Amanda; Blomkvist, Camilla; Johansson, M., Lindeberg, A., Blomkvist, C., \& Johansson, M. (8003). Understanding the relationship between Brand identity and Brand image - A case study of Coop. Methodolgy / Brand, 102. https://doi.org/2012

Saputra, F. I. (2013). Service Quality, Image and Its Effect on Loyalty through Customer Satisfaction (Study at PT Bank Bni 46 Surabaya Small Credit Centers). Management Application, 11 (3), 445-457. https://doi.org/10.1016/j.eneco.2016.05.009

Sastha P, G. A. W. N., \& Wardhana, A. (2016). Influence of Brand Image on Customer Loyalty (Study on Simpati Card Customers in Denpasar City). 3 (November 2015), 1-5.

Sulibhavi, B., \& K, S. (2017). The Impact of Brand Image on Customers' Loyalty Towards Private Label Brands: the Mediating Effect of Satisfaction. Hubli-Dharwad Conglomerate City of Karnataka. International Journal of Marketing \& Financial Management, 5 (8), 43-50. Retrieved from www.arseam.com

Syoalehat, Q. N., Azizah, S., \& Kusumastuti, E. (n.d.). Pak Man's grilled meatballs Malang City. 26 (3), 20-26. 